\title{
PERTANGGUNGJAWABAN PIDANA BAGI PRAJURIT YANG MELAKUKAN TINDAK PIDANA PENCURIAN DENGAN PEMBERATAN STUDI KASUS PUTUSAN NOMOR 85-K/PM.II- 09/AD/VII/2018 DI PENGADILAN MILITER II-09 BANDUNG
}

\author{
Eky Anggun Lestari, Musa Darwin Pane \\ Fakultas Hukum Universitas Komputer Indonesia \\ musa@email.unikom.ac.id
}

\begin{abstract}
The common crime is theft with various types that are backed up because of the unfulfilled needs of life. Theft crimes with the circumcision is a normal theft in its implementation accompanied by certain incriminated circumstances, for example is done by Allied two or more actors and performed at night. The problems examined were how the enforcement and implementation of criminal sanctions for TNI soldiers who committed criminal acts with the exposure in the study of the Decree No. 85-K/PM. II09/AD/VII/2018. The research methods used are as follows, the specification of this research using analytical Deskriftif is by research method by providing the data and facts of primary, secondary and tertiary legal materials. The method of approach used is the normative juridical which focuses on the research on legal norms, legal rules whereas field studies are used to obtain primary data obtained from agencies with problems Research.. The research methods used are as follows, the specification of this research using analytical Deskriftif is by research method by providing the data and facts of primary, secondary and tertiary legal materials. The method of approach used is the normative juridical which focuses on the research on legal norms, legal rules whereas field studies are used to obtain primary data obtained from agencies with problems Research.

Keywords: Accountability; Theft by Granting Weights; Military; Criminal experiments
\end{abstract}

\begin{abstract}
ABSTRAK
Kejahatan yang sering terjadi adalah pencurian dengan berbagai jenis yang dilatarbelakangi karena kebutuhan hidup yang tidak tercukupi. Tindak pidana pencurian dengan pemberatan merupakan pencurian biasa yang dalam pelaksanaannya disertai oleh keadaan tertentu yang memberatkan, misalnya dilakukan dengan bersekutu dua atau lebih pelaku dan dilakukan pada malam hari. Permasalahan yang dikaji adalah bagaimana penegakan dan penerapan sanksi pidana bagi prajurit TNI yang melakukan tindak pidana dengan pemberatan dalam studi putusan Nomor 85-K/PM.II-09/AD/VII/2018. Metode penelitian yang digunakan yaitu sebagai berikut, spesifikasi penelitian ini menggunakan Deskriftif Analitis yaitu dengan metode penelitian dengan cara memberikan data-data dan fakta bahan hukum primer, sekunder dan tersier. Metode pendekatan yang digunakan yaitu secara yuridis normatif yang menitikberatkan pada penelitian terhadap norma-norma hukum, kaidah hukum sedangkan studi lapangan digunakan untuk memperoleh data primer yang diperoleh dari instansi dengan masalah penelitian. Putusan Perkara Nomor 85-K/PM.II-09/AD/VII/2018 yaitu tentang tindak pidana pencurian dengan pemberatan yang dilakukan seorang militer dan teman sipil lainnya. Peraturan Mahkamah Agung Nomor 2 Tahun 2012 tidak hanya bersinggungan dengan Kitab Undang-Undang Hukum Pidana saja, melainkan bersinggungan juga dengan Pasal 205 Kitab UndangUndang Hukum Acara Pidana, dalam kasus tersebut hakim menjatuhkan pidana bersyarat yaitu Pidana Penjara selama 4 (empat) bulan dengan masa percobaan 6 (enam) bulan.
\end{abstract}

Kata Kunci : Pertanggungjawaban; Pencurian dengan Pemberatan; Militer; Pidana Percobaan 


\section{PENDAHULUAN}

Kejahatan pencurian yang tidak hanya dilakukan di kota besar saja tetapi sampai kepelosok daerah. Salah satu bentuk kejahatan yang sering terjadi adalah pencurian dengan berbagai jenis yang dilatarbelakangi karena kebutuhan hidup yang tidak tercukupi. Terlebih lagi tidak hanya dilakukan warga sipil namun prajurit Tentara Nasional Indonesia (TNI). Secara ideal kalangan TNI-lah senantiasa diharapkan menjadi panutan bagi masyarakat yang lain. TNI dalam kapasitasnya sebagai aparat Negara haruslah menjadi panutan masyarakat sehingga hubungan dengan rakyat tetap terjalin baik, hal ini berarti bahwa citra TNI perlu dijaga khususnya oleh prajurit TNI itu sendiri. Tentara Nasional Indonesia sangat besar untuk mengawal dan menyelamatkan bangsa dan negara TNI merupakan suatu instansi yang mempunyai tingkat kedisiplinan yang tinggi, karena memang fungsi dan tugas dari ini cukup berat.

Persamaan kedudukan dalam hukum dan pemerintahan tersebut dapat mencakup dalam kehidupan bermasyarakat yaitu terhadap siapa yang melanggar hukum atau pemerintahan yang berlaku, pasti akan mendapatkan sanksi yang sesuai dengan berat ringannya pelanggaran hukum itu. Di Indonesia sebagai Negara hukum didasarkan pada konsep hukum pancasila yang menjadi landasan konsep dan dasar kebijakan hukum. Teori negara hukum merupakan konsekuensi dari pilihan asas bangsa Indonesia atas hukum sebagaimana yang tersirat dalam jiwa falsafah bangsa Indonesia dan UUD 1945 tentang tujuan negara hukum Indonesia. Identitas negara hukum Indonesia bersumber dari nilai-nilai pancasila sebagai falsafah hidup berbangsa dan bernegara rakyat Indonesia.

Pasal 1 Bab I Undang-Undang Nomor 25 Tahun 2014 tentang Hukum Disiplin Militer menyebutkan Militer adalah anggota kekuatan angkatan perang suatu negara yang diatur berdasarkan ketentuan peraturan perundang-undangan. Hukum tidak memandang siapa itu pejabat, rakyat biasa/aparat pertahanan keamanan dan penegak hukum di Indonesia, jika melanggar hukum akan mendapatkan sanksi sesuai dengan perbuatan yang dilakukan. Dibentuknya lembaga peradilan militer tidak lain untuk menindak para prajurit TNI yang melakukan tindak pidana, menjadikan salah satu alat kontrol dalam menjalankan tugasnya. Sehingga dapat membentuk dan membina TNI yang kuat, profesional dan taat hukum. TNI terdiri dari 3 yaitu TNI terdiri dari tiga angkatan bersenjata yaitu TNI Angkatan Darat, Angkatan Laut dan Angkatan Udara. Salah satu contoh kasus mengenai pencurian dengan pemberatan yang dilakukan oleh prajurit TNI dan sipil sesuai dengan Putusan Pengadilan Militer II-09 Bandung Nomor 85-K/PM.II-09/AD/VII/2018.

Berdasarkan latar belakang yang dikemukakan diatas maka dapat disimpulkan rumusan masalah sebagai berikut, Bagaimana penegakan hukum terhadap Prajurit Tentara Nasional Indonesia yang melakukan pencurian dengan pemberatan serta Bagaimana penerapan sanksi pidana bagi Prajurit Tentara Nasional Indonesia yang melakukan tindak pidana dengan pemberatan studi kasus putusan No.85-K/PM.II09/AD/VII/2018 di Pengadilan Militer II-09 Bandung?

\section{METODE PENELITIAN}

Metode penelitian yang digunakan yaitu sebagai berikut, spesifikasi penelitian ini menggunakan Deskriptif Analitis yaitu dengan metode penelitian dengan cara memberikan data-data dan fakta bahan hukum primer, sekunder dan tersier. Metode pendekatan yang digunakan yaitu secara yuridis normatif yang menitikberatkan pada penelitian terhadap norma-norma hukum, kaidah hukum sedangkan studi lapangan 
digunakan untuk memperoleh data primer yang diperoleh dari instansi dengan masalah penelitian.

\section{PEMBAHASAN}

1. Penegakan Hukum Terhadap Prajurit Tentara Nasional Indonesia Yang Melakukan Pencurian dengan Pemberatan

Seorang Prajurit Tentara Nasional Indonesia berkedudukan sama seperti masyarakat umum atau sipil lainnya, artinya apabila Prajurit TNI melakukan pelanggaran atau melakukan tindak pidana maka Prajurit tersebut akan mendapatkan sanksi sebagaimana yang diatur dalam Undang-Undang Dasar 1945 Pasal 28 D ayat 1 yaitu: "Setiap orang berhak atas pengakuan, jaminan, perlindungan, dan kepastian hukum yang adil serta perlakuan yang sama di hadapan hukum". Bahkan sanksi terhadap pelaku pelanggaran atau tindak pidana bagi prajurit TNI akan dirasakan lebih berat daripada masyarakat umum atau sipil, hal ini disebabkan bahwa seorang prajurit TNI seyogyanya mengerti akan aturan-aturan, norma-norma yang telah mengikat kepada jati dirinya sebagai Prajurit TNI.

Perkara Sertu Wahyudi nomor Putusan 85/K/PM.09-AD/VII/208 ini merupakan tindak pidana campuran atau yang biasa disebut dalam KUHP adalah koneksitas. Menurut Pasal 89 KUHP pengertian koneksitas adalah sebagai berikut:

"Tindak pidana yang dilakukan bersama-sama oleh mereka yang termasuk lingkungan peradilan umum dan lingkungan peradilan milliter, diperiksa dan diadili oleh pengadilan dalam lingkungan peradilan umum kecuali jika menurut keputusan Menteri Pertahanan dan Keamanan dengan persetujuan Menteri Kehakiman perkara itu harus diperiksa dan diadili oleh pengadilan dalam lingkungan peradilan militer"

Masalah mengenai koneksitas diatur pada Pasal 89 sampai dengan Pasal 94 Kitab Undang-Undang Hukum Pidana. Namun sejak tahun 2000, koneksitas sudah tidak dipakai lagi di Indonesia. Dikarenakan alasan proses yang lama, mengeluarkan biaya tidak sedikit yang sangat bertentangan dengan asas peradilan cepat sederhana dan biaya yang ringan.

2. Penerapan Sanksi Pidana bagi Prajurit Tentara Nasional Indonesia yang Melakukan Tindak Pidana Pencurian dengan Pemberatan Studi Kasus Putusan Nomor 85-K/PM.09/AD/VII/2018 di Pengadilan Militer II-09 Bandung.

Perkara Sertu Wahyudi nomor Putusan 85/K/PM.09-AD/VII/208 tertanggal 23 Oktober 2018 bahwa yang melakukan tindak pidana pencurian, dimana pencurian dilakukan dua orang atau lebih dengan cara bersekutu bersama-sama dengan orang umum atau sipil. Terdakwa Sertu Wahyudin setelah ia menyerahkan diri ke Datim Intel Korem 03/Sgj kemudian ditindak lanjuti dan langsung di BAP selanjutnya Denpom III/03 Cirebon melengkapi BAP dengan memeriksa para saksi dan tersangka, setelah lengkap berkas dilimpahkan ke Oditurat Militer II-08 Bandung dari oditurat Militer II-09 
Bandung, kemudian disidangkan di Kodim 0620 Sunan Gunung Jati Cirebon. Unsur-unsurnya yang didakwakan yaitu sebagai berikut;

a. Unsur kesatu adalah pencurian

Bahwa "pencurian" dengan tindak pidana pencurian dengan unsur pemberatan mempunyai arti yang sama dengan pencurian dalam bentuk pokok, akan tetapi pencurian yang ditambah unsur lain yang telah tercantum Pasal 363 KUHP yang bersifat memberatkan pelaku, sehingga ancaman pidananya lebih berat dari pidana pencurian dalam bentuk pokok.

Unsur ke 1a: barang siapa

Unsur ke $1 \mathrm{~b} \quad$ : mengambil barang sesuatu

Unsur ke 1c : yang seluruhnya atau sebagian milik orang lain

Unsur ke 1d: dengan maksud untuk dimiliki secara melawan hokum

b. Unsur kedua, yang dilakukan oleh dua orang atau lebih dengan bersekutu.

Yang dimaksud dengan dilakukan oleh dua orang atau lebih dengan bersekutu yaitu perbuatan tersebut dilakukan oleh minimal 2 (dua) orang atau lebih. Bersekutu dalam hal ini tidak diisyarakatkan diantara mereka jauh sebelum tindakan tersebut terjadi, yang penting bahwa pada saat tindakan dilakukan sudah ada saling pengertian diantara mereka, kendati tidak terperinci, lalu selanjutnya bekerja sama maka kerja sama/bersekutu tersebut telah terjadi. Dalam hal ini pencurian dilakukan oleh Prajurit TNi dan 3 orang teman sipil. Setelah diperiksa, diadili dan diputus ternyata terdakwa dan teman sipil lainnya mengambil lempengan besi perahu yang sudah lama tidak bertuan. Peran Terdakwa adalah menyediakan mobil truk Engkel Mitsubishi Nopol E 8503 B, mengangkut potongan lempengan besi yang telah dipotong-potong oleh Saksi-1 (Sdr. Nana Suryana) dan Saksi-4 (Sdr. Sudirman) adalah Terdakwa dengan Saksi-3 (Sdr. Yuyu Wahyudiana). Lempengan yang diambil laku terjual ditaksir beratnya kurang lebih 5 kwintal dan diperkirakan harga perkilonya sejumlah $\mathrm{Rp} 2.500,00$ (dua ribu lima ratus rupiah), apabila terjual diperkirakan harga seluruhnya kurang lebih sejumlah $\mathrm{Rp} 1.250 .000,00$ (satu juta dua ratus lima puluh ribu rupiah).

Penyidikan dalam perkara ini hanya dilakukan saat itu masih statusnya sebagai Tersangka yaiu Sertu Wahyudin dan sampai disidangkan dan diputus pidana bersyarat, sedangkan kepada para pelaku tindak pidana lain yang masyarakat umum atau sipil tidak dilakukan penyelidikan dan penyidikan dengan alasan yang diambil yaitu barang berupa lempengan besi perahu yang sudah lama tidak bertuan (tidak ada pemiliknya) juga nilai yang dicuri tidak melebihi sejumlah $\mathrm{Rp}$ 2.500.000,000 (dua juta lima ratus ribu rupiah) karena berpatok kepada Peraturan Mahkamah Agung Republik Indonesia Nomor 02 Tahun 2012 tentang Penyesuaian Batasan Tindak Pidana Ringan dan Jumlah Denda dalam KUHP. 
Setelah Majelis mempertimbangkan dalam hal-hal yang meringankan dan memberatkan sifat, hakekat, akibat maupun hal-hal yang mempengaruhi perbuatannya, maka memidana Terdakwa Sertu Wahyudin dengan pidana bersyarakat yaitu Pidana Penjara selama 4 (empat) bulan dengan masa percobaan 6 (enam) bulan. Dengan perintah pidana tersebut tidak usah dijalani, kecuali jika di kemudian hari ada putusan Pengadilan yang menentukan lain karena terpidana melakukan kejahatan atau pelanggaran Disiplin Prajurit TNI, sebagaimana tercantum dalam Pasal 8 Undang-Undang Republik Indonesia Nomor 25 Tahun 2014 tentang Hukum Disiplin Militer, sebelum masa percobaan tersebut habis.

Pidana bersyarat tersebut dengan alasan demi kepentingan Militer karena tenaga dan pikiran terdakwa sangat diperlukan di kesatuan tempat terdakwa berdinas dibandingkan terdakwa menjalani pidana di Lembaga Pemasyarakatan Militer (LEMASMIL) agar tenaga Terpidana dapat dimanfaatkan di Kesatuan. Penulis beranggapan bahwa penerapan sanksi pidana yang dijatuhkan oleh Pengadilan Militer terhadap terpidana wahyudin sangat tidak sesuai, dengan alasan yaitu :

a. Terpidana adalah seorang prajurit TNI yang mengerti akan peraturan-peraturan yang berlaku dan norma-norma yang melekat kepada dirinya, sehingga seyogyanya dijatuhi hukuman yang lebih berat.

b. Tindak Pidana yang dilakukan oleh terpidana merupakan tindak pidana pencurian dengan pemberatan dengan dilakukan oleh tiga orang dan 1 orang prajurit militer (Pasal 362 jo 363 ayat (1) angka 4 KUHP).

c. Tuntutan oditur militer dirasa tidak sesuai dengan rasa keadilan, dikarenakan tuntutan yang diajukan kepada hakim pengadilan militer hanya empat bulan penjara, padahal Pasal 140 Kitab Undang-Undang Hukum Pidana Militer menyebutkan ancaman tindak pidana pencurian yang dilakukan oleh seorang anggota militer adalah tujuh tahun.

d. Mengingat terpidana adalah seorang militer maka sekiranya sanksisanksi pidana yang dicantumkan didalam Kitab Undang-Undang Hukum Pidana kurang berat maka dapat ditambah sepertiga (Pasal 52 Kitab Undang-undang Hukum Pidana).

e. Peraturan Mahkamah Agung RI Nomor 2 Tahun 2012 seharusnya tidak diberlakukan terhadap si terpidana, dikarenakan ancaman pidana yang diatur didalam Pasal 362 jo 363 ayat (1) angka 4 KUHP yaitu tujuh tahun.

f. Peraturan Mahkamah Agung Nomor 2 Tahun 2012 tidak hanya bersinggungan dengan Kitab Undang-Undang Hukum Pidana saja, melainkan bersinggungan juga dengan Pasal 205 Kitab UndangUndang Hukum Acara Pidana, dalam kasus tersebut hakim menjatuhkan pidana bersyarat yaitu Pidana Penjara selama 4 (empat) bulan dengan masa percobaan 6 (enam) bulan dimana hakim tersebut mempunyai pertimbangan didasarkan pada barang bukti yang bernilai kurang dari dua juta lima ratus ribu rupiah, padahal unsur yang paling mendasar adalah syarat dilakukannya 
pemeriksaan tindak pidana ringan di Pasal 205 Kitab UndangUndang Hukum Acara Pidana ialah perkara yang diancam dengan pidana penjara atau kurungan paling lama tiga bulan, dan atau denda sebanyak-banyaknya tujuh ribu lima ratus rupiah, unsur yang paling penting yaitu ancaman hukumannya tidak lebih dari tiga bulan dan dari pasal tersebut tidak terdapat unsur nilai barang atau uang yang dijadikan tindak pidana, melainkan yaitu denda yang tidak melebihi tujuh ribu lima ratus rupiah jika dikalikan seribu menjadi tujuh juta lima ratus ribu rupiah, sehingga tidaklah tepat jika terpidana disidangkan dengan acara pemeriksaan tindak pidana ringan padahal perkara ini termasuk tindak pidana pencurian dengan pemberatan dengan dilakukan oleh tiga orang sipil dan 1 orang prajurit militer (Pasal 362 jo 363 ayat (1) angka 4 KUHP).

\section{SIMPULAN}

Berdasarkan hasil penelitian dan pembahasan yang telah diuraikan di atas, maka penulis dapat menarik kesimpulan sebagai berikut;

Tindak pidana yang dilakukan oleh seorang militer dan beberapa orang sipil dalam perkara No.85-K/PM.II-09/AD/VII/2018 di Pengadilan Militer II-09 ini bukan termasuk ke dalam perkara koneksitas karena sejak tahun 2000 koneksitas sudah tidak dipakai lagi di Indonesia. Dikarenakan prosesnya tidak efesien, waktu lama dan membutuhkan biaya yang tidak sedikit. Perkara tindak pidana yang dilakukan bersama-sama oleh militer dan sipil sekarang langsung diadili di pengadilan masingmasing. Setelah diperiksa, diadili dan diputus ternyata terdakwa Sertu Wahyudin dan teman sipil lainnya mengambil lempengan yang sudah lama tidak bertuan. Lempengan yang diambil laku terjual ditaksir mencapai kurang lebih Rp.1.250.000,00 (satu juta lima ratus rupiah). Peraturan Mahkamah Agung Nomor 2 Tahun 2012 tidak hanya bersinggungan dengan KUHP saja, melainkan bersinggungan juga dengan Pasal 205 KUHP, dalam kasus tersebut hakim menjatuhkan pidana bersyarat yaitu Pidana Penjara selama 4 (empat) bulan dengan masa percobaan 6 (enam) bulan dimana hakim tersebut mempunyai pertimbangan didasarkan pada barang bukti yang bernilai kurang dari dua juta lima ratus ribu rupiah, padahal unsur yang paling mendasar adalah syarat dilakukannya pemeriksaan tindak pidana ringan di Pasal 205 Kitab Undang-Undang Hukum Acara Pidana ialah perkara yang diancam dengan pidana penjara atau kurungan paling lama tiga bulan, dan atau denda sebanyak-banyaknya tujuh ribu lima ratus rupiah, unsur yang paling penting yaitu ancaman hukumannya tidak lebih dari tiga bulan dan dari pasal tersebut tidak terdapat unsur nilai barang atau uang yang dijadikan tindak pidana, melainkan yaitu denda yang tidak melebihi tujuh ribu lima ratus rupiah jika dikalikan seribu menjadi tujuh juta lima ratus ribu rupiah, sehingga tidaklah tepat jika terpidana disidangkan dengan acara pemeriksaan tindak pidana ringan tetapi tetap dimasukan kedalam tindak pidana murni.

\section{DAFTAR PUSTAKA}

Bambang Waluyo. Pidana dan Pemindanaan. Sinar Grafika. Jakarta. 2008.

Dito Astawansyah, 'Tinjauan Kriminologis Tentang Kejahatan Pencurian Kendaraan

Bermotor Roda Dua', (Skripsi yang telah dipublikasikan, Program Strata-1

Ilmu Hukum, Fakultas Hukum Universitas Hasanudin, 2013). 
Imanuel Marchel. Tinjauan Terhadap Penjatuhan Sanksi Bagi Anggota TNI Yang Melakukan Tindak Pidana Insubordanasi. [2017]. Jurnal Hukum Universitas Atma Jaya Yogyakarta.

Musa Darwin Pane. Pengganti Kerugian Negara Dalam Tindak Pidana Korupsi. Logoz Publishing. Bandung. 2017.

Sahat Maruli T. Situmeang. Penahanan Tersangka Diskresi dalam Proses Peradilan Pidana. Logoz Publishing. Bandung. 2017.

Surahman, 'Tinjauan Yuridis Terhadap Delik Pencurian yang Dilakukan Oknum Anggota Tentara Nasional Indonesia' (Skripsi Yang Telah Dipublikasikan, Program Strata-1 Ilmu Hukum, Fakultas Hukum Universitas Hasanudin, 2014).

Ummi Mufarrikah, 'Disparitas Pidana Terhadap Tindak Pidana Pencurian dengan Pemberatan yang dilakukan oleh Prajurit TNI' (Skripsi yang dipublikasikan, program Strata-1 Pendidikan Ilmu Hukum. Fakultas Hukum Universitas Negeri Semarang, 2015).

Undang-Undang Dasar 1945.

Kitab Undang-Undang Hukum Pidana

Kitab Undang-Undang Hukum Acara Pidana.

Undang-Undang Republik Indonesia Nomor 31 tahun 1997 tentang Peradilan Militer.

Undang-Undang Republik Indonesia Nomor 25 tahun 2014 tentang Hukum Disiplin Prajurit Angkatan Bersenjata Republik Indonesia.

Peraturan Mahkamah Agung Nomor 2 Tahun 2012 tentang Penyesuaian Batasan Tindak Pidana Ringan dan Jumlah Denda dalam KUHP.

Surat Edaran Mahkamah Agung Nomor 2 Tahun 2014 tentang Penyelesaian Perkara di Pengadilan Tingkat Pertama dan Tingkat Banding pada 4 (empat) Lingkungan Peradilan. 